\title{
CHANGES IN FUNCTIONAL USE OF DISPERSED SETTLEMENTS IN SLOVAKIA (CASE STUDY NOVOBANSKÁ ŠTÁLOVÁ AREA)
}

DOI: http://dx.doi.org/10.18509/GBP.2015.53

UDC: 911.372.2(439.2)

\author{
RNDr. Lucia Šolcová, PhD. \\ RNDr. Magdaléna Nemčíková, PhD. \\ RNDr. PaedDr. Ján Veselovský, PhD. \\ RNDr. Hilda Kramáreková, PhD.
}

Constantine the Philosopher University in Nitra, Faculty of Natural Sciences, Department of Geography and Regional Development, Slovakia

\begin{abstract}
All regions with dispersed settlements have a special type of geographic character which is conditioned by the arrangement of settlements, depending on geology and surface, soils and forest cover area. The creation of this specific settlement is affected by other factors, e.g. population movements caused by military events. Base of dispersed settlements are particularly highlands, the amount of which varies most often between 500 - 800 m.a.s.l. In mountain areas, dispersed settlements are found in mountain valleys or on the hillsides generally performed from one central village. The human factor worked for the transformation of forest to pasture, then the fields so in most of those areas have been dispersed settlements character. The article analyzes the settlement of Slovakia on the example of "Novobanská štálová" area. Based on the knowledge of the settlement of the region as well as field research, objective is to identify the contribution of changes in land use in the context of its historical development.
\end{abstract}

KEYWORDS: Dispersed settlement. "Novobanská štálová" area. Land use.

\section{INTRODUCTION}

Dispersed ("kopanica") settlement is one of the few preserved historical landscape structures in Slovakia. This type of settlement is an autonomous manifestation of socioeconomic activity which is conditioned by specific natural and historical conditions. It developed as a product of colonization moves in Slovakia and its genesis was territorially and time significantly differentiated [3].

In order to understand the causes and consequences of changes in landscape with dispersed settlement, the multidisciplinary research based on historical context is needed. In terms of the mentioned, the aim of this paper is a causal analysis of landscape changes in two typical municipalities with dispersed settlement (Župkov and Píla) belonging to the "Novobanská štálová" area.

\section{THEORETICAL APPROACHES TO THE ISSUE}

Dispersed or "kopanica" settlement which was formed from the half of the 15th century to the 18th century, when it reached its peak, was closely linked to the land use [3]. Since there was a lack of agricultural land, which would be provided to population, "kopanica" land was obtained by culturing the forest soil or draining of wet areas and drying out wetlands. When dispersed settlements we being created, also other moments could affect them e.g. population movements caused by military events, it could have a pastoral 
character, in areas with more developed mining production (e.g. in the study area) the "kopanica" settlement was associated with exploitation of ore deposits and especially with logging and burning of charcoal for ironworks. Gradually, most of the "kopanica" people, according to the local circumstances, also dealt with growing of the most needed agricultural crops. The emergence of "kopanica" settlements was also affected by the physical-geographical characteristics of the area [2]. The upper boundary of settlements was condition, in particular, by relief and climate. Agrarian settlements extended in the 11th-12th century to the elevation of 500 m.a.s.l. and later to about 700 m.a.s.l. [4].

Dispersed settlements and secluded dwellings were formed in mountainous and foothill areas because of colonization of forested areas as originally pastoral settlements. They developed from low-lying chalets, farm buildings arranged for winter stays in remote or difficult to access fields. There are two ways for the form of dispersed settlements. One group has the form of free chain villages where houses are spread at certain distances from one another and generally in one direction. The settlement stretches very far usually along the valley of the stream. The second form is the group - one original property and house was divided to several properties and houses near the old house ("štál"). In Slovakia there 5 areas with dispersed settlements were identified [2]. As a result of significant expansion, the dispersed settlements have different regional names. In the north-west part of Slovakia from Myjava town to Orava region they are called "kopanice", in the Orava region they are called "rale", in central Slovakia from Tisovec town to Krupina town they are named as "lazy", west and north from the Nová Baňa town they are called "štále".

\section{METHODS}

The complexity of the research of landscape development requires an application of a combination of several approaches, concepts, research methods, and techniques. The methodological base is based on several empirical studies which were analyzed in terms of their research methodologies; this is defined by the integrated analysis or the following synthesis of natural, historical, social, and economic conditions of the area.

The first step was to delimit the study area and analysis of natural and socio-economic conditions. The territory of "Novobanská štálová" area was chosen because of the fact that it is the territory with historically valuable landscape structure where the boundary of Protected Landscape Area of Ponitrie extends. Moreover, there are also sites which are proposed into the system of European protected areas - NATURA 2000. Analysis of the natural conditions of the landscape is represented by an offer of natural environment in terms of land use. Analysis of the socio-economic characteristics pointed to the influence of human factor on the land use.

The next step was to analyze historical documents about the area. Land use, which is historically very variable and dynamic, causes changes in landscape structure. When monitoring the changes in landscape structure, also historical documents are important (written and cartographic) while historical maps provide information on land cover or land use changes. To assess the historical landscape structure of the area, we used historical maps from 1844 (2nd Military Survey) as well as historical documents and map outputs which were obtained from the archives and historical publications. Using the spatial identification of landscape elements, we analyzed the land use of the area [8].

Terrain mapping we conducted with the support of orthophotos and contour maps of the state map series of the Slovak Republic. At this stage, we focused on the mapping of current status and results were confronted with maps at a scale of 1:10 000 and 1:25000. 
Furthermore, the aim of the field research was to make a photographic documentation of the study area.

Regarding the research in landscape and subsequent processing of the results, we used several methods. Historical-geographical method was applied for the analysis of historical documents and the characteristics of the historical development of the study area. Cartographic method was applied when creating map layouts for partial analysis of physical-geographical conditions [6]. Mathematical-statistical methods were used for calculations of indicators in tables and graphs. Methods of landscape-ecological planning, GIS and remote sensing enable to objectively monitor and evaluate these changes.

\section{LOCATION AND DELINEATION OF THE STUDY AREA}

"Novobanská štálová" area was formed mainly in connection with mining, charcoal making, logging, glass making, and grazing on the basis of the arrival of German population in the 14th century in the period of mining development [5]. At first they were only seasonal residences which later changed into permanent settlements. The area has 31,373 ha and it consists of 14 municipalities from three districts: Žarnovica, Zlaté Moravce, and Prievidza. The largest area accounts for the Žarnovica District which includes municipalities of Župkov, Píla, Vel'ké Pole, Hrabičov, Horné Hámre, Žarnovica and only one town of Nová Baňa. It also includes municipalities of Radobica, Horná Ves, Oslany, and Čereňany which are located in the district of Prievidza and municipalities of Jedl'ové Kostol'any, Malá Lehota a Vel'ká Lehota in the Zlaté Moravce District. The "štál" area is located in the mountains of Vtáčnik, Tribeč, Pohronský Inovec, and Štiavnické vrchy. The issue of land use change in the municipalities with dispersed settlements was addressed also by [7], [11], [12].

The model area has two municipalities - Župkov and Píla (Map 1). Píla municipality has an area of 2,579 ha and Župkov municipality covers 1,034 ha which together represents $11.5 \%$ of the total size of "štál" area. In 2012, the population of the Píla municipality was 144 (population density of 5.58 inhabitants $/ \mathrm{km}^{2}$ ), the municipality of Župkov had 860 inhabitants (population density of 83.17 inhabitants $/ \mathrm{km}^{2}$ ).

\section{RESULTS}

Changes in land use or landscape structure affect the environment and biodiversity of the area. The most visible indicators of the change are changes in land cover or secondary landscape structure (SLS). Changes of SLS can be seen in the context of the away to the sawmill in order to build mines and also to the Žarnovica ironworks. The development of agriculture conditioned the arrangement of SLS and partially modified properties of primary landscape structure (relief, soil characteristics). The influence of human factors on the arrangement change of landscape is noticeable and also agrarian historical landscape structures can be found there. In the SLS they are identified as meadows, fields such as the archaic agricultures with the structure of differently arranged historical fields. Rare settlements allowed leaving the exhausted soil and gradually use other available land areas also in higher-lying areas. 


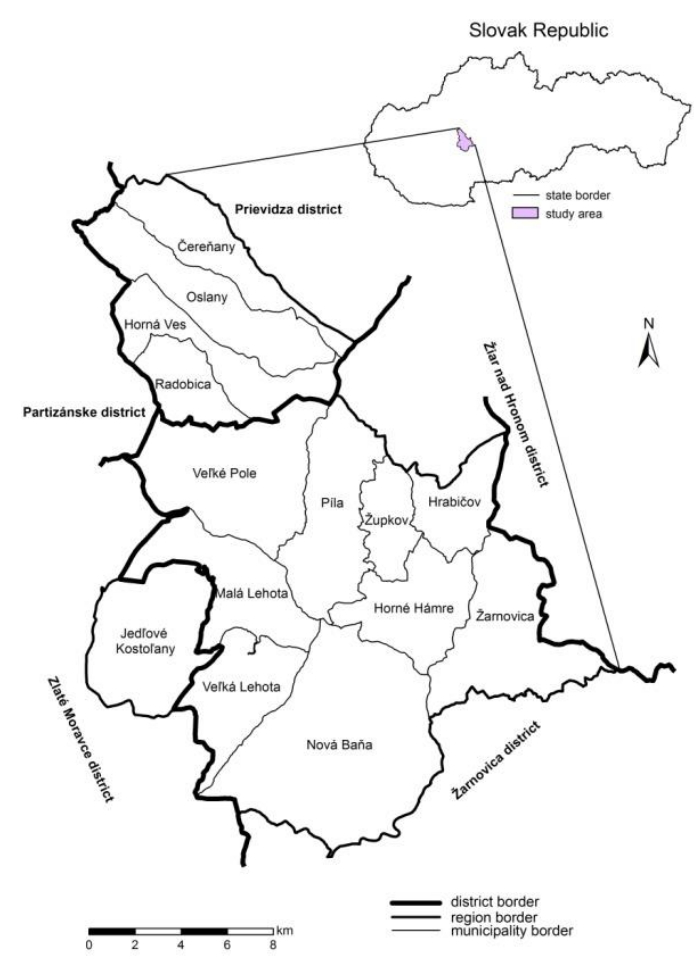

Map 1 The territory of "Novobanská štálová" area

away to the sawmill in order to build mines and also to the Žarnovica ironworks. The development of agriculture conditioned the arrangement of SLS and partially modified properties of primary landscape structure (relief, soil characteristics). The influence of human factors on the arrangement change of landscape is noticeable and also agrarian historical landscape structures can be found there. In the SLS they are identified as meadows, fields such as the archaic agricultures with the structure of differently arranged historical fields. Rare settlements allowed leaving the exhausted soil and gradually use other available land areas also in higher-lying areas.

For the evaluation and comparison of changes in landscape structure in the study area, we selected three time horizons 1844-1956-2013 which represent the period of 169 years. We analyzed the land use in each year and pointed out the changes between them.

According to Table 1, the municipality of Župkov can be considered a stable landscape in the period of 1844-2013 because up to $68.5 \%$ (708.2 ha) of the municipality area remained unchanged.

According to Table 2 and Figure 2, the group of elements of forest and non-forest woody vegetation changed in the period of $1844-1956-2013$ by 365.2 ha (35.3\%). These forest complexes preserved mainly in the northern part of the municipality. The group of elements of permanent grasslands preserved on the area of 329.3 ha $(31.8 \%)$. This group can be mainly found in the central part of Župkov municipality. The third group is the group of elements of agricultural crops and it maintained on 98.6 ha (9.5\%). It occurs mainly along rivers and some parts of "štále" called "Andelovci", "Dolný Župkov" and "Horné Pecno". The group of residential elements and recreational areas increase during the studied period from 8.5 ha $(0.8 \%)$ to 61.7 ha $(6.0 \%)$ which was an increase of 53.2 ha. A substantial part of the population was concentrated mainly along the Župkovský potok (stream). 
Table 1 Changes in land use in the municipality of Župkov in the period of 1844-2013

\begin{tabular}{|c|r|r|r|r|}
\hline \multirow{2}{*}{ Time horizons } & \multicolumn{3}{|c|}{ Changed } & \multicolumn{3}{c|}{ Unchanged } \\
\cline { 2 - 6 } & ha & \% & ha & \% \\
\hline $1844-1956$ & 418.2 & 40.4 & 616.2 & 59.6 \\
\hline $1956-2013$ & 526.9 & 50.9 & 507.5 & 49.1 \\
\hline $1844-2013$ & 326.2 & 31.5 & 708.2 & 68.5 \\
\hline
\end{tabular}

Table 2 Land use in the municipality of Župkov in the period of $1844-1956-2013$

\begin{tabular}{|l|r|r|r|r|r|r|}
\hline \multirow{2}{*}{ Groups of landscape elements } & \multicolumn{2}{|c|}{$\mathbf{1 8 4 4}$} & \multicolumn{2}{c|}{$\mathbf{1 9 5 6}$} & \multicolumn{2}{c|}{$\mathbf{2 0 1 3}$} \\
\cline { 2 - 7 } & \multicolumn{1}{c|}{ ha } & \multicolumn{1}{c|}{ ha } & \multicolumn{1}{c|}{ ha } & \multicolumn{1}{c|}{$\%$} \\
\hline 1 Group of elements of forest and non-forest woody vegetation & 434.7 & 42.0 & 365.2 & 35.3 & 544.4 & 52.6 \\
\hline 2 Group of elements of permanent grasslands & 390.0 & 37.7 & 592.9 & 57.3 & 329.3 & 31.8 \\
\hline 3 Group of elements of agricultural crops & 201.2 & 19.4 & 61.6 & 6.0 & 98.6 & 9.5 \\
\hline 4 Group of residential elements and recreational areas & 8.5 & 0.8 & 14.7 & 1.4 & 61.7 & 6.0 \\
\hline 5 Group of technical elements & - & - & - & - & 0.3 & 0.0 \\
\hline
\end{tabular}

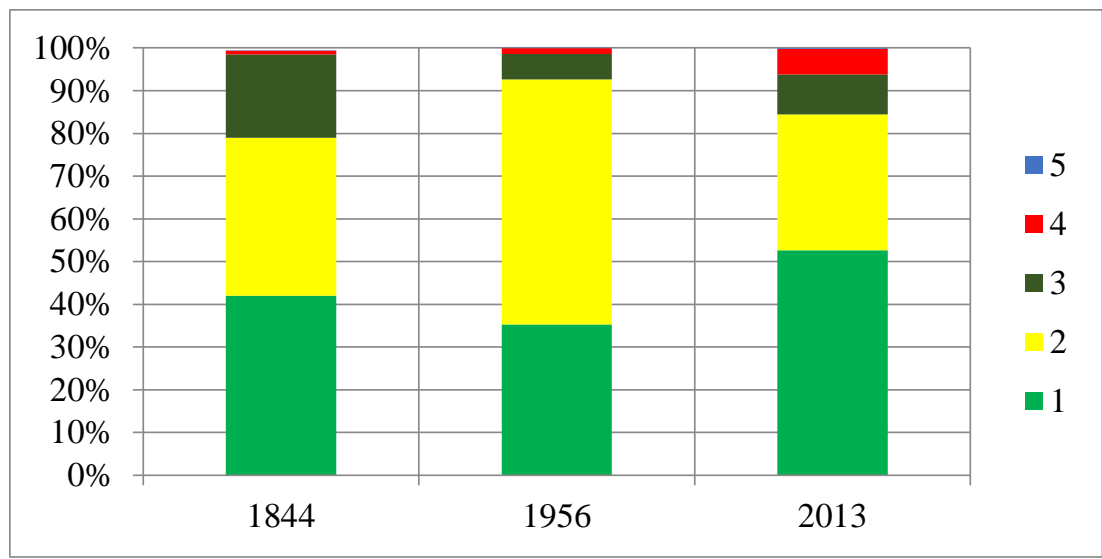

Figure 2 Changes in land use in the municipality of Župkov

In terms of location and relation of "kopanice" settlements to their nuclei, we can distinguish [9]: municipalities with "kopanice" spatially distributed around the center (nucleus) of the municipality; municipalities with "kopanice" spatially distributed along one side of the municipality and along the main communication; municipalities with "kopanice" along both sides of the centre converging to the communication axis; municipalities with "kopanice" having a central (core, primary) center, also secondary centres and a number of solitery settlements. An example of this type is the municipality of Píla (Figure 3) which has a relatively large territory and long history of its formation.
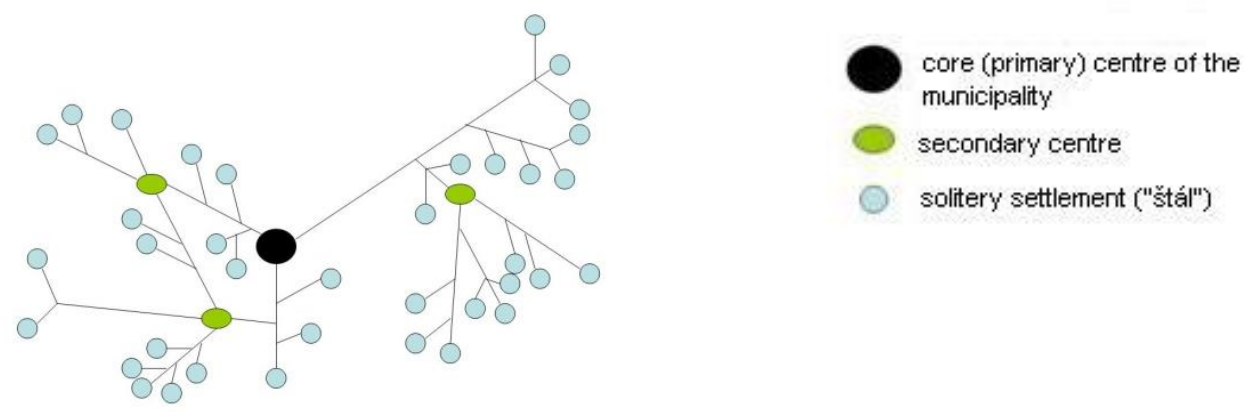

Figure 3 Municipality of Píla as a specific morphological type of "kopanice" settlement 
The land use in the municipality of Píla remained unchanged during the studied period $(61.5 \%)$ representing 1,585.6 ha (Table 3). From this value, the highest share is represented again by forest areas 923.9 ha $(35.8 \%)$ which are predominantly localized west of the Tabernov rigol (ditch) and Markov vrch (hill). Continuous areas can be found also in the north and south part of the municipality in the highest elevations of Vtáčnik and Tribeč mountains.

Table 3 Changes in land use in the municipality of Píla in the period of 1844-2013

\begin{tabular}{|c|r|r|r|r|}
\hline \multirow{2}{*}{ Time horizons } & \multicolumn{2}{|c|}{ Changed } & \multicolumn{2}{c|}{ Unchanged } \\
\cline { 2 - 5 } & ha & \multicolumn{1}{c|}{ \% } & \multicolumn{1}{c|}{ ha } \\
\hline $1844-1956$ & 1078.0 & 41.8 & 1501.0 & 58.2 \\
\hline $1956-2013$ & 373.0 & 14.5 & 2206.0 & 85.5 \\
\hline $1844-2013$ & 993.4 & 38.5 & 1585.6 & 61.5 \\
\hline
\end{tabular}

According to Table 4 and Figure 3, the group elements of permanent grasslands remained unchanged in the period of 1844-1956-2013 representing 310.7 ha (12.1\%). Continuous areas can be found south-east of Markov vrch (hill) where there is gradual change to permanent grasslands with trees i.e. succession. Other areas can be found in the area of Tabernov rigol (ditch), in the south-east part of the municipality, and they are also along Pílanský potok (stream) and Čierny potok (stream). Group of elements of agricultural crops remained unchanged with the value of 194.5 ha (7.5\%). The elements of this group preserved unchanged in the "štál" area and Hossov rigol (ditch). There is a change of arable land to permanent grasslands. The group of residential elements and recreational areas remained unchanged in the area of 27.7 ha $(1.1 \%)$.

The studied period of 1844-1956-2013 is on one side a long time horizon (169 years), but in spite of that we can talk about the study area as a stable landscape. This is confirmed by the fact that more than half of the size of study area $(61.5 \%)$ during the whole period did not change its use. The most stable is the group of elements of forest and non-forest vegetation and also group elements of permanent grasslands.

The most dynamic seems to be the group of agricultural crops, especially, around urban areas. Within this group, there were some changes from small-scale to large-scale fields and vice versa. In the group of residential elements and recreational areas, the most stable part of the settlement appears to be the center (core) of municipalities. A significant part of population is concentrated along the main road and in the centre of municipality where there is a Roman Catholic church, municipal office, and primary school.

Table 4 Land use in the municipality of Píla in the period of $1844-1956-2013$

\begin{tabular}{|l|r|r|r|r|r|r|}
\hline \multirow{2}{*}{ Groups of landscape elements } & \multicolumn{2}{|c|}{$\mathbf{1 8 4 4}$} & \multicolumn{2}{c|}{$\mathbf{1 9 5 6}$} & \multicolumn{2}{c|}{$\mathbf{2 0 1 3}$} \\
\cline { 2 - 6 } & \multicolumn{1}{c|}{ ha } & \multicolumn{1}{c|}{ ha } & \multicolumn{1}{c|}{ \% } & \multicolumn{1}{c|}{ ha } & \multicolumn{1}{c|}{$\%$} \\
\hline 1 Group of elements of forest and non-forest woody vegetation & 1816.2 & 70.4 & 1377.6 & 53.4 & 1550.9 & 60.1 \\
\hline 2 Group of elements of permanent grasslands & 310.7 & 12.1 & 847.5 & 32.9 & 800.7 & 31.0 \\
\hline 3 Group of elements of agricultural crops & 428.5 & 16.6 & 334.6 & 13.0 & 194.5 & 7.5 \\
\hline 4 Group of residential elements and recreational areas & 23.6 & 0.9 & 14.9 & 0.6 & 27.7 & 1.1 \\
\hline 5 Group of technical elements & - & - & 0.6 & 0.0 & 3.5 & 0.1 \\
\hline
\end{tabular}




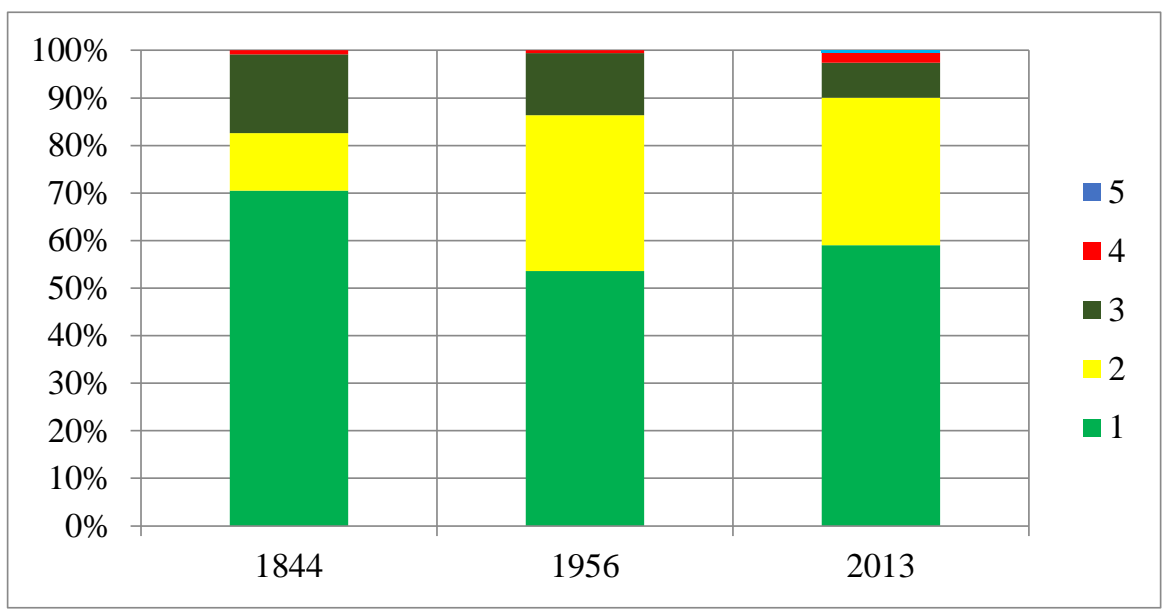

Figure 3 Changes in land use in the municipality of Píla

Overall, we record the trend of stabilization in the group of elements of forest and nonforest woody vegetation as well as in the group of permanent grassland, change of primary function of "štál" areas for recreational function, minimal employment opportunities and displacement of young people to near larger towns.

Nearly half of the area (less than 40\%) changed its function at least once for the whole period. The biggest changes occurred between the two groups: group of forest and nonforest woody vegetation and group of permanent grasslands, but also between the group of agricultural crops and group of permanent grasslands. The reasons for these changes are the intensive land use, removal of forest cover and its transformation to meadows, pastures, and arable land.

\section{CONCLUSION}

Analyses of the landscape structure development have an important application aspect. Based on knowledge of processes of landscape structure formation from the past to the present, we can predict the development of landscape and guide it in order to maintain and increase landscape diversity as well as quality of life of local residents or visitors.

We can claim that the studied dispersed settlement remained generally unchanged. However, it is losing its primary residential function and the secondary function starts to prevail - recreation associated with cottage dwelling [10] or its disappearance. The decline of job opportunities and outflow of young people to the wider background is reflected in the number of unoccupied houses. Abandonment of individual "štál" sites led to the disappearance of several of them. Moreover, demogeographic indicators show the gradual dissipation of the area. On the other hand, the territory has a high potential for tourism development because it is located in attractive landscape for tourists. 


\section{REFERENCES}

[1] Horváth, P. Historický prehl'ad vzniku a rozvoja chotárnych sídiel v slovenskej časti Karpát. In: Slovenský národopis, 28, 1, Slovak Republic, 1980, pp. 8-18.

[2] Hromádka, J. Všeobecný zemepis Slovenska. Slovak Republic, 1943. 256 p.

[3] Huba, M. O perspektívach kopaničiarskeho osídlenia a kopaničiarskej krajiny na území Slovenskej republiky. In: Geografický časopis, roč. 42, č. 2., 1990, Slovak Republic, pp. 113-130.

[4] Chalupa, P. \& Hübelová, D. Sídelní struktury. Mendelova univerzita v Brně, Czech Republic, 2011, 101 p.

[5] Krogmann, A. Vyst'ahovalectvo z Dolného Saska na Slovensko, jeho príčiny a kultúrne vplyvy. In: Geografické informácie 11, Slovak Republic, 2007, pp. 143-150.

[6] Oláhová, J. \& Vojtek, M. \& Boltižiar, M. Development of Secondary Landscape Structure in the Village of Cigel' from the Late 18th Century In: Scientia iuvenis : Book of Scientific Papers, Slovak Republic, 2012, pp. 262-267.

[7] Petrovič, F. Vývoj krajiny v oblasti štálového osídlenia Pohronského Inovca a Tribeča. Slovak Republic, 2005, 209 p.

[8] Rampašeková, Z. Pedogeographic characteristics of selected area. In: Geography and Geoinformatics: Challenge for Practise and Education : Proceedings of 19th International Conference, Brno, 8. - 9. September 2011. Czech Republic, 2011, pp. 241-249.

[9] Sitár, E. Kopaničiarske osídlenie na Slovensku (niektoré otázky súčasného stavu). In : Vlastivedný časopis, Bratislava, vol. 16, no. 3, Slovak Republic, 1967, pp. 125-135.

[10] Svorad, A. \& Krogmann, A. Evaluation of Tourist Attractiveness in the Poprad District Through Statistical Materials. In: Scientia iuvenis: Book of Scientific Papers. Slovak Republic, 2014, pp. 289-296.

[11] Šolcová, L. Vývoj krajiny s disperzným typom osídlenia v Novobanskej štálovej oblasti. 2012, Slovak Republic, 208 p.

[12] Vojtek, M. Súčasná krajinná štruktúra povodia Vyčomy. Geografické štúdie. 2012. Vol. 16, No. 1, Slovak Republic, pp. 75-85. 